\title{
THE EFFECT OF PEDAGOGICAL CONTENT KNOWLEDGE (PCK) LEARNING MANAGEMENT TOWARD LEARNING OUTCOMES THROUGH STUDENT LEARNING MOTIVATION IN PHYSICS
}

\author{
Aan Juhana Senjaya ${ }^{*}$, Maman Rakhmanudin², Ipong Dekawati ${ }^{3}$ \\ 1,2,3 Universitas Wiralodra, Indramayu, Indonesia \\ *aan.juhana.senjaya@unwir.ac.id
}

\begin{abstract}
Article Info
Article history

Received: January 18, 2021

Revised:March 22, 2021

Accepted March 29, 2021

Keywords: Learning

Management; Learning

Motivation; Learning outcomes;

Pedagogical Content

Knowledge

ABSTRACT

Research on physics learning management has not been done much, especially regarding PCK and learning outcomes. Many studies that investigate the relationship between variables use the regression method. However, this study uses path analysis. The purpose of this study was to measure the direct effect, indirect effect, and total effect of PCK, learning motivation, and student physics learning outcomes using path analysis. The research method used in this research is a survey with a quantitative approach and data analysis techniques, namely path analysis. The data collection technique used a closed questionnaire. This study's sample was 43 teachers who gathered from 64 high school physics teachers in Indramayu Regency. The PCK learning management research results had no significant effect on student learning outcomes, learning motivation had a positive effect, and learning motivation had a positive effect on student learning outcomes. The implication of this study that the principal and the education office should continue to strive to improve the quality and smoothness of the teaching and learning process by providing provision to teachers to improve pedagogical content knowledge (PCK) learning management by participating in workshops and continuously improving techniques to motivate students for results student learning better.
\end{abstract}

\section{INTRODUCTION}

An educational process's success can be seen from students' learning outcomes (Sudjana, 2014). Therefore, it is essential to pay attention to student learning outcomes to improve education quality and quality. One of the phenomena of Indonesian education is the low quality and quality of education reflected in learning outcomes. The Program for International Student Assessment (PISA), under the Organization for Economic Cooperation and Development (OECD), the year 2015 conducted a survey in several countries on literacy achievement and published it in 2016. Of the 70 countries surveyed, Indonesia ranked Bottom 62 or 10 (OECD, 2016).

Based on the international survey results, one indicator is that Indonesia's quality of education is still far from what is expected. The quality of education, one of which saw from the literary achievements of reading, mathematics, and science, can be reflected in 
students' learning outcomes in pursuing education. Based on the international survey above shows that student learning outcomes in Indonesia are still low.

Learning outcomes are indicators of success in the teaching and learning process pursued by students. Learning is said to be successful if it gets results at least the same as the Minimum Mastery Criteria (MMC) set by each school according to its conditions. The MMC is a limitation for students to achieve the desired learning outcomes. Students expected to get good learning outcomes by achieving or exceeding the specified MMC.

Many problems faced by the education unit. One of the problems most often faced is the low learning outcomes obtained by students. Not a few learning outcomes obtained by students are under the Minimum Mastery Criteria (MMC). This low learning outcome is an indicator of the quality of the learning process and students' quality. It is reinforced by the data on the average value of the National Examination results in Physics Subjects in Table 1.

Table 1 Average National Examination Results (UN) for High School Physics Subjects in Indramayu Regency in years 2016, 2017, 2018, 2019

\begin{tabular}{lll}
\hline Years & Average & Percentage \\
\hline 2016 & 60.47 & - \\
2017 & 43.19 & $-28.6 \%$ \\
2018 & 41.69 & $-3.5 \%$ \\
2019 & 39.94 & $-4.2 \%$ \\
\hline \multicolumn{2}{r}{ Source:puspendik.kemendikbud.go.id }
\end{tabular}

Based on the average value of the national exam results (UN) in table 1, it can say that from 2016 to 2018, there was a decline in the average value of the national exam results, the most significant drop occurred in 2017, which was $-28.6 \%$ from the previous year. Furthermore, in 2019 there was a decrease in the average value of national examination results in physics subjects by $-4.2 \%$ from the previous year. These results indicate that learning outcomes are still low and become a problem that must be considered. It is reinforced by the average value of the Final Semester Assessment results (PAS) in physics subjects at SMA Negeri 1 Lohbener, Indramayu Regency, odd semester 2019/2020, as shown in Table 2.

Table 2. Average Final Semester Assessment Results (PAS) in Physics Subjects at SMA Negeri 1 Lohbener, Indramayu Regency

\begin{tabular}{lll}
\hline School & Average Value & Category MMC \\
\hline SMA 1 Lohbener & 53.17 & Under MMC \\
Average & 60.00 & Under MMC \\
\hline
\end{tabular}

Source: Physics teacher assessment, (data processed) 2019/2020 Academic Year

Students' learning outcomes are very closely related to the formulation of instructional goals planned by the teacher beforehand, grouped into three categories (realms): cognitive, affective, and psychomotor domains (Jihad \& Haris, 2013). 
According to Purwanto (2017), the success or failure of learning depends on various factors. The factors are divided into two, namely individual factors (internal) and social factors (external). Included in individual factors include maturity/growth, intelligence, exercise, motivation, and personal factors. In contrast, those included in social factors include family/ household conditions, teachers and how to teach them, tools used in learning, environmental and social motivation. Other than that, the learning process's success affects the skills possessed by the teacher, such as pedagogic skills, content skills, and knowledge skills (Hadi et al., 2019).

Based on the statement above, it is clear that learning is an essential process in determining learning outcomes and influenced by students' internal and external factors. So it can be said that these factors influence learning outcomes. Student internal factors that influence learning outcomes are their motivation in learning. Furthermore, external factors that can affect students are a teacher. An external factor influencing student learning outcomes, in this case, is a teacher. A teacher's role as a manager in learning management reflected in every ability related to the learning process. In "managing" or managing learning, managers, in this case, the teacher, carry out various activities ranging from teaching and learning plan, organizing learning, directing, and evaluating learning. Understanding such learning management can be interpreted broadly in encompassing the whole activity of how to teach students from teaching and learning plan to learning assessment. Another opinion states that learner management can interpret as a management process that includes planning, organizing, controlling, and evaluating activities related to learning the learner by including various factors in it to achieve learning objectives (Sagala, 2013).

Learning management that can improve student learning outcomes is a management activity carried out by the teacher starting from planning learning, organizing learning, directing, and evaluating learning done by applying pedagogical content knowledge (PCK) in the learning process.

The concept of PCK has attracted much attention (Doyle et al., 2018). Science teachers' PCK has researched in many studies, including the Relating Teacher PCK and Teacher Practice Using Classroom Observation (Barendsen, 2017), application of PCK frameworks to design and technology (D\&T) education, through an analysis of the nature of the discipline from an ontological and epistemological perspective and contemporary perspectives on the construct of PCK (Doyle, 2018), concurrently examine self-regulated learning processes (SRL) and learning outcomes of three teachers in professional development (PD) on argumentation in science to assess the relationship between types of learning processes employed by teachers and corresponding learning outcomes (Erin, 2020), how teachers learn to teach a new topic and the role played by their developing content 
knowledge as they teach (Rollnick, 2016), and The Impact of Physics Teachers' Pedagogical ContentKnowledge and Motivation on Students' Achievement and Interest (Keller, 2017).

The research that the above researchers have conducted has not tested the effect of PCK on learning outcomes through learning motivation in physics, but the effect is tested jointly with PCK. It can happen that PCK does not have a direct effect on learning outcomes but through learning motivation. For this reason, this study will examine the effect of PCK learning management both directly and indirectly on learning outcomes through motivation to learn physics. It will clarify the effect of each independent variable on the dependent variable. The bias will reduce.

\section{METHODS}

\subsection{Design}

This study uses an abductive approach with quantitative methods that underlying positivism philosophy. This type of research is correlational research, to be precise path analysis. The research constellation can see in Figure 1.

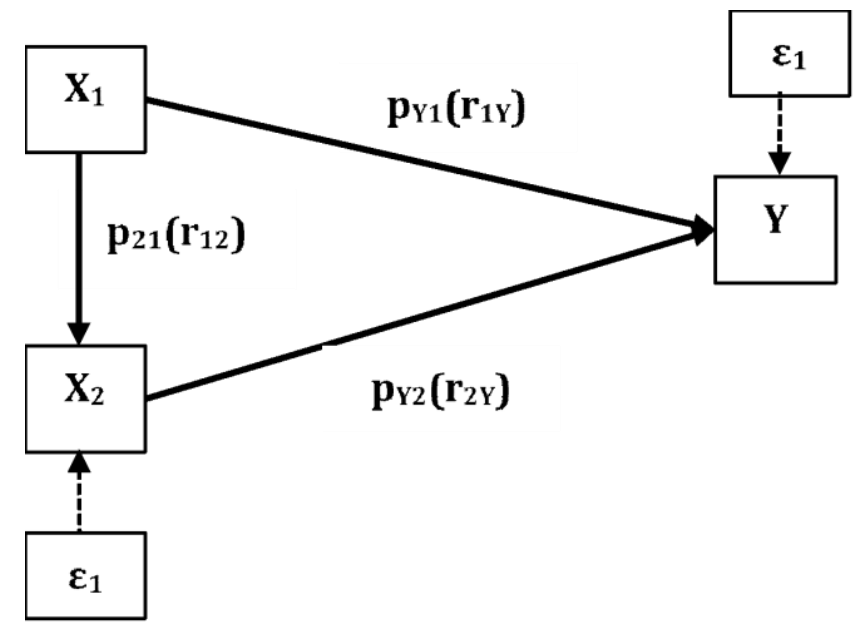

Figure 1. Medium Path Model (Senjaya, 2018)

The primary data to be collected is data about physics learning outcome variables (Y), pedagogical content knowledge learning management variables PCK $\left(X_{1}\right)$, and student learning motivation variables $\left(X_{2}\right)$. To collect the data, each uses an instrument in the form of a questionnaire. The instrument quality criteria are sufficient to meet the criteria (a) the items are valid and (b) the instrument is reliable (Senjaya, 2018: 17). Test the validity of instrument items using the Product Moment formula and test instrument items' reliability using the Alfa Cronbach formula. To test the validity and reliability used statistical calculation tools through the 2019.02 PESTRIPS program.

Instrument Student learning outcomes

Studen's learning outcomes instrument consists of 26 Likert scale items. After the test, two items dropped, so only 24 items were used. The item validity correlation coefficient 
ranged from 0.25 to 0.79 . As for calculating the reliability coefficient using Cronbach's alpha coefficient and obtained a reliability coefficient of 0.93 .

\subsection{PCK instrument}

It consists of 45 statement items with a Likert scale. After being tested, there were four invalid items. Thus, 41 items used to collect data with a correlation coefficient ranging from 0.31 to 0.80 . The reliability coefficient is 0.94 .

\subsection{Learning motivation instrument}

It consists of 25 items questionnaire with a Likert scale, and after being tested for validity, there are only 24 items with a correlation coefficient ranging from 0.30 to 0.78 . consists of 25 Items questionnaire with a Likert scale, and after being tested for validity, there are only 24 items with a correlation coefficient ranging from 0.30 to 0.78 . The coefficient, using Cronbach's alpha coefficient, is 0.93 .

\subsection{Data analysis}

The population of this research is high school physics teachers in Indramayu Regency. The Research strategy is a survey and instrument of data collection techniques administered to 43 physics teachers as samples from 64 physics teachers. The sample size was determined using the table from Krejcie \& Morgan (Krejcie, 1970). Statistical calculation aids using LISREL 8.80 software and PESTRIPS 2019.02 (Senjaya, 2018).

Based on Figure 1, the model to be tested is as follows:

$X_{1}=p_{21}$

$X_{2}=p_{21} \cdot X_{1}+\varepsilon_{1}$

$Y=P_{Y 1} . X_{1}+p_{Y 2} . X_{2}+\varepsilon_{2}$

Notes:

Y: Learning Outcomes Variable

$X_{1}$ : PCK Management Variable

$X_{2}$ : Learning Motivation Variable

p: path coefficient

r: correlation coefficient

$\varepsilon$ : residual or error

The model above can analyze by using the Path Analysis method. Path analysis is one of the analyses that applied with correlational analysis. Path analysis is a statistical technique to illustrate the directed engagement between several variables. The path diagram and the research hypothesis into an empirical data correlation equation and its structural equation, Senjaya (2018).

Correlation equation: 
$r_{12}=p_{21}$

$r_{1 Y}=p_{Y 1}+p_{Y 2} \cdot r 12$

$r_{2 Y}=p_{Y 1 . r 12}+p_{Y 2}$

Structural equation:

$\mathrm{X}_{1}=\mathrm{p}_{21}$

$X_{2}=p_{21} \cdot X_{1}+\varepsilon 1$

$Y=p_{Y 1} \cdot X_{1}+p_{Y 2} \cdot X_{2}+\varepsilon_{2}$

\section{RESULTS AND DISCUSSION}

\section{RESULTS}

3.1. Effect of PCK Learning Management towards Learning Outcomes Motivation.

To measure PCK Learning Management's path coefficient $\left(X_{1}\right)$ towards Learning Motivation $\left(\mathrm{X}_{2}\right)$ used GAMMA output from the LISREL 8.80 program. GAMMA output is LISREL output in the form of an influence matrix between exogenous variables $\left(X_{1}\right.$ and $\left.X_{2}\right)$ to endogenous variables $(\mathrm{Y})$.

\section{GAMMA}
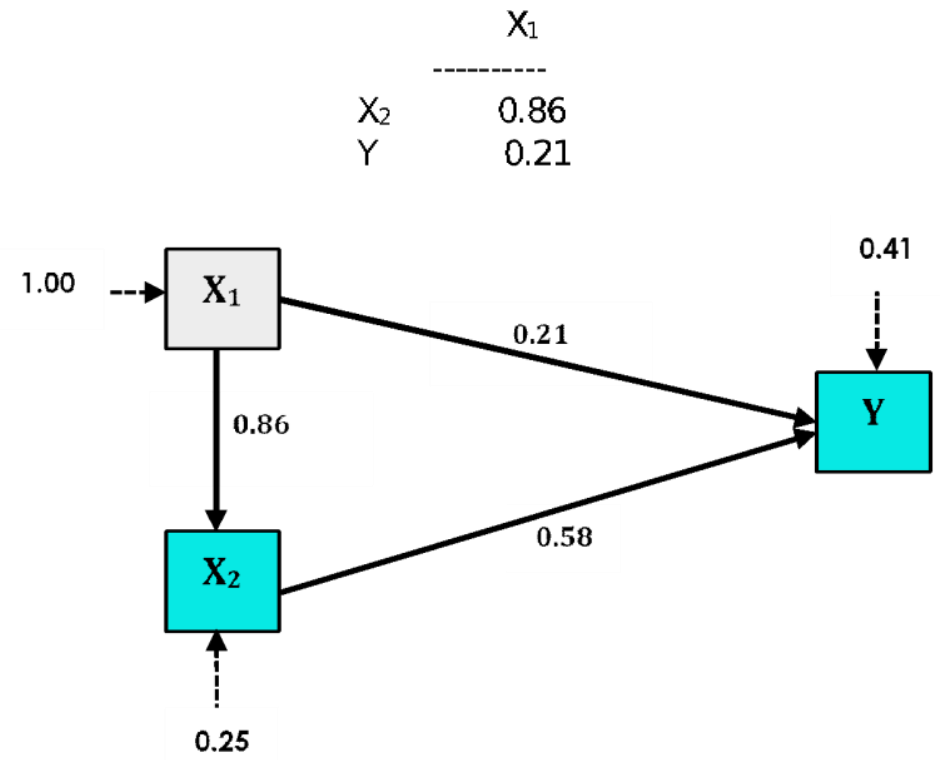

Chi-Square $=0.00, d f=0, P$-value $=1.00$, RMSEA $=0.000$

Figure 2. The effect of PCK student learning outcomes through Learning Motivation

Based on the Gamma output and Figure 2 above, the path coefficient value of the influence between PCK $\left(X_{1}\right)$ and Learning Motivation $\left(X_{2}\right)$ is $0.86\left(p_{12}=0.86\right)$. The direct influence of Learning Management Pedagogical Content Knowledge (PCK) on Learning Motivation of 0.86 . To test the significance or insignificance of the influence of $P C K\left(X_{1}\right)$ on Learning Motivation ( $\mathrm{X}_{2}$ ) by t-test, pay attention to the t-test output (T-Value) of the LISREL program in Figure 3. 
Based on Figure 3, the T-Value output, the relationship between PCK Learning Management $\left(X_{1}\right)$ and Learning Motivation $\left(X_{2}\right)$ is significant because the value of $\dagger>$ critical $\dagger$ value $(t=11.02>+$ critical $=1.96)$. Meaning: Management of pedagogical content knowledge learning has a positive effect on learning motivation. The influence of pedagogical content knowledge management learning on learning motivation is $0.86\left(p_{12}=\right.$ 0.86).

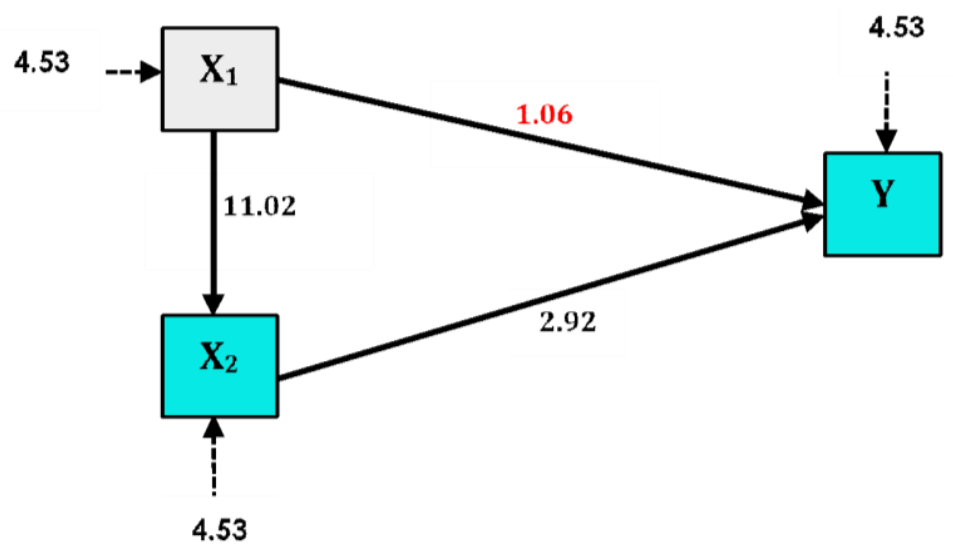

Chi-Square $=0.00, \mathrm{df}=0, \mathrm{P}$-value $=1.00, \mathrm{RMSEA}=0.000$

Figure 3. The effect of PCK student learning outcomes through Learning Motivation T-Test

The influence of other variables (besides learning motivation) can saw from the residual coefficient of the following LISREL program output:

\section{PSI}

Note: This matrix is diagonal

$\begin{array}{rr}X_{2} & Y \\ -0.25 & 0.41\end{array}$

PSI output displays output regarding measurement error only for endogenous variables $\left(X_{2}\right.$ and $\left.Y\right)$, where standardized error $X_{2}$ has measurement error $(\varepsilon=0.25)$. It means that the influence of other variables (besides learning motivation) affects $25 \%$.

\subsection{The Effect of PCK Learning Management Variables $\left(X_{1}\right)$ on Student Learning Outcomes (Y)}

This path analysis was conducted to determine the effect of PCK on student learning outcomes. To measure PCK Learning Management's path coefficient $\left(X_{1}\right)$ on student learning outcomes (Y), then look at GAMMA output from the LISREL 8.80 program above.

GAMMA output is LISREL output in the form of an influence matrix between exogenous variables $\left(X_{1}\right.$ and $X_{2}$ ) to endogenous variables $(Y)$. Based on the GAMMA output, the path coefficient between the PCK $\left(X_{1}\right)$ learning outcomes towards student learning outcomes $(Y)$ is 0.21 ( $\mathrm{P}_{Y 1}=0.21$ ). PCK $\left(X_{1}\right)$ Learning Management's direct effect on student learning outcomes $(\mathrm{Y})$ is 0.21 . 
While the indirect effect obtained with the following LISREL output.

Standardized Total and Indirect Effects

Standardized Total of $X$ on $Y$

$\mathrm{X}_{1}$

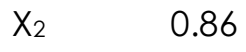

$\begin{array}{ll}Y & 0.71\end{array}$

Standardized Indirects Effects of $X$ on $Y$

$\mathrm{X}_{1}$

$\mathrm{X}_{2}$

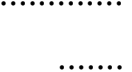

Y $\quad 0.50$

Standardized Total Effects of $Y$ on $Y$

$\mathrm{X}_{2}$

Y

$X_{2}$

Y $\quad 0.58$

Based on the LISREL output above the indirect effects $X_{1}$ to $Y$ of 0.50 . So that the total impact of $X_{1}$ on $Y$ is 0.71 , pay attention to the LISREL output above. To test the significance or insignificance of the influence of Pedagogical Content Knowledge Learning Management (PCK) $\left(X_{1}\right)$ on student learning outcomes $(Y)$ by t-test, pay attention to the t-test output (TValue) of the LISREL program. Based on the T-Valve output, the relationship of PCK) Learning Management $\left(X_{1}\right)$ to student learning outcomes $(Y)$ is not significant because the value of $t<$ $\dagger$ value is critical $(\dagger=1.05<\dagger$ critical $=1.96)$. Meaning: Management of pedagogical content knowledge learning has not a significant direct effect on student learning outcomes. However, it has effects indirectly on learning outcomes through learning motivation.

The influence of other variables (which the authors did not examine) can be seen from the residual coefficient of the following LISREL program PSI output above. PSI output displays output regarding measurement error only for endogenous variables ( $\mathrm{X} 2$ and $\mathrm{Y}$ ) where the error is standardized $Y$ has measurement error $(\varepsilon=0.41)$. That means that the influence of other variables not examined the effect of $41 \%$.

\subsection{The Effect of Learning Motivation Variables $\left(X_{2}\right)$ on Student Learning Outcomes $(Y)$.}

The path analysis used to determine Learning Motivation $\left(X_{2}\right)$ on Student Learning Outcomes $(Y)$. To measure the path coefficient of the variable Learning Motivation $\left(\mathrm{X}_{2}\right)$ on Student Learning Outcomes (Y), then see the BETA output from the LISREL 8.80 program. The BETA output is LISREL output in a relationship matrix between endogenous variables $\left(\mathrm{X}_{2}\right.$ and Y). 


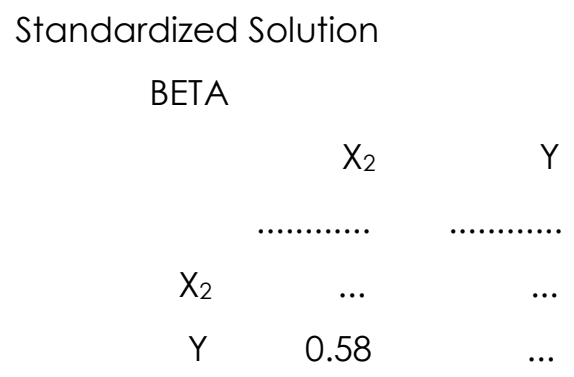

Based on the BETA output obtained by the value of the path coefficient of influence between variables Learning Motivation $\left(\mathrm{X}_{2}\right)$ on Student Learning Outcomes $(\mathrm{Y})$ of 0.58 ( $\mathrm{P}_{\mathrm{Y} 2}=$ 0.58). The variable Learning Motivation ( $\left.\mathrm{X}_{2}\right)$ 's direct effect on Student Learning Outcomes $(Y)$ is 0.58 . Table 4 shows the direct, indirect, and total influence between the dependent and independent variables.

Table 2 Decomposition of Influence Between Variables

\begin{tabular}{llll} 
& & & \\
Effect of Variables & Effect & Total \\
\cline { 2 - 3 } & direct & indirect & \\
\hline$X_{1} \square X_{2}$ & 0.86 & - & 0.86 \\
$X_{1} \square X_{2} \square Y$ & 0.21 & $(0.86)(0.58)=0.50$ & $0.21+0.50=0.71$ \\
$X_{2} \square Y$ & 0.58 & - & 0.58 \\
\hline
\end{tabular}

Test the significance or insignificance of the influence of Learning Motivation $\left(\mathrm{X}_{2}\right)$ variables on Student Learning Outcomes $(Y)$ by t-test paid attention to the t-test output (TValue) of the LISREL program. Based on the T-Value output above that the relationship of Learning Motivation $\left(\mathrm{X}_{2}\right)$ to Student Learning Outcomes $(\mathrm{Y})$ is significant because the value of $\dagger>$ critical $\dagger$ value $(t=2.92>$ critical $t=1.96)$. Meaning: Learning motivation has a positive effect on student learning outcomes. The influence of learning motivation on student learning outcomes is 0.58 ( $\left.\mathrm{pr}_{2}=0.58\right)$.

\subsection{The effect of the other variables known from the residual coefficient from the following LISREL program output.}

PSI output (above) displays output regarding measurement error only for endogenous variables $\left(X_{2}\right.$ and $Y$ ) where standardized error $X_{2}$ has a measurement error $(\varepsilon=0.25)$, and $Y$ has a measurement error $(\varepsilon=0.41)$. Based on the LISREL output above, the influence of other variables (besides pedagogical content knowledge learning management and learning motivation) is $41 \%$ (Figure 2).

Furthermore, to determine the suitability of the research model or measurement model with empirical data. The path analysis model above was then tested for feasibility by looking at the probability value of $P>0.05$ and the value of Root Mean Square Error of Approximation (RMSEA) $<0.05$. From the LISREL output $P$ values $=1.00>0.05$ and RMSEA $=$ $0.00<0.05$. That means that the model is Fit. The following outputs are the model conclusions from LISREL. 


\author{
Goodness of Fit Statistics \\ Degree of Freedom $=0$ \\ Minimum Fit Function Chi-Square $=0.0(P=1.00)$ \\ Normal Theory Weighted Least Squares Chi-Squares $=0.00(P=1.00)$
}

The Model is Saturated, and the Fit is Perfect!

\title{
3.5. Direct Effect of Learning Management PCK on Physics Learning Outcomes
}

The problem that will answer in this research is that there is a direct and significant influence toward PCK learning on physics student learning outcomes in-state high schools in the Indramayu region. Empirically, the results of this study's learning management on student physics learning outcomes appear from the correlation coefficient $\left(r_{1 Y}=0.71\right)$. However, the effect's magnitude was not significantly from the path coefficient's value ( $P_{Y 1}=0.21$ ). Based on the t-test obtained value $<$ critical $\dagger$ value $(t=1.05<$ critical $t=1.96)$. Mean Management of pedagogical content knowledge learning has an insignificant effect on student learning outcomes-however, its effects indirectly through learning motivation.

\subsection{Direct Effect of Learning Management PCK Against Learning Motivation.}

Based on the results of this study, it found that there was a significant positive effect toward PCK of high school physics subjects in the Indramayu region on student motivation with a contribution of $75 \%\left(R^{2}=0.75\right)$, the rest influenced by other variables not examined in this study by $25 \%(\varepsilon=0.25)$. Based on the description, the effectiveness of learning depends on teachers' ability to manage the class. Teachers who have good classroom management skills can maintain the teaching and learning conduciveness and vice versa. Related to classroom management, teachers need to understand the characteristics of students, that the attributes of students in-state high schools in Indramayu Regency that study physics are so varying, that teachers must determine precisely the ways and strategies for delivering subject matter. Variative learning strategies can eliminate students' boredom in the teaching and learning process; that determination of learning strategies differs from one teacher to another following the students' characteristics. This variation can increase students' fun and motivation in learning, support, and the teacher needs to appreciate each student's learning activities.

\subsection{Direct Effect of Student Learning Motivation on Physics Learning Outcomes.}

The problem to be answered in this study is that there is a positive and significant influence on learning motivation on students' learning outcomes in physics at state high schools in the Indramayu region. Based on empirical findings that indicate a significant influence of learning motivation on student learning outcomes, this study provides some information, including 1) an increase in learning motivation has a significant effect on student learning 
outcomes in physics in school, 2) one way to improve student learning outcomes is to increase learning motivation, 3) the percentage of the effect of learning motivation is $59 \%$ $\left(R^{2}=0.59\right)$, and the rest influenced by other variables namely pedagogical content knowledge learning management (PCK) and other variables not examined in this study.

\subsection{The Effect of PCK learning management on Physics Learning Outcomes Through Learning Motivation}

The results showed an indirect effect. It is evidenced by the output of LISREL (indirect effects) $X_{1}$ to $Y$ by 0.50 . Also (indirect effects of $X$ on $Y$ ) or pedagogical content knowledge (PCK) learning management on student learning outcomes through learning motivation is significant. The value of $\mathrm{P}>0.05$ evidences it. It can conclude that learning motivation was influenced by PCK learning management and affects student learning outcomes. The higher the pedagogical content knowledge learning management (PCK), the higher the learning outcomes of students and the increase in learning motivation. The complete causal relationship diagram can be illustrated empirically from the test results in Figure 2.

Value of $P=1.00>0.05$ and RMSEA $=0.00<0.05$. Then the research model (hypothetical model) is in fits with empirical data. So Figures 2 becomes an empirical model of the relationship between pedagogical content knowledge learning management (PCK) $\left(X_{1}\right)$, learning motivation $\left(X_{2}\right)$, and student learning outcomes $(Y)$.

\section{DISCUSSION}

Regarding the correlation between PCK and learning motivation, this study's results are in line with Maryani's (2015) research that studies correlation between Teacher's PCK (Pedagogical Content Knowledge and Student's Motivation in Primary School. However, not in line with Cheng's (2020) research examines the correlation between teachers' PCK (Pedagogical Content Knowledge) and Student's Motivation in Primary School.

The research results on the relationship between PCK and learning outcomes showed that the effect was not significant. This result is inconsistent with Creasy's (2012) research with microevolution material, Lange (2012), which states that teachers' PCK was significantly related to student achievement in elementary science after controlling for crucial students' teacher-level covariates. Likewise with Jasmina (2017), who researched The Effects of Professors 'Pedagogical Content Knowledge on Elementary Teacher Candidates' Attitude and Achievement Regarding Biology.

The results of research on the relationship between learning motivation and learning outcomes show a significant effect. These results align with Wu's (2016) research which discusses the Effects of Multimedia Information Technology Integrated Multi-Sensory Instruction on Students' Learning Motivation and Outcome. These results are also in line with 
Rafiola's (2020) research which examines The Effect of Learning Motivation, Self-Efficacy, and Blended Learning on Students' Achievement in Industrial Revolution 4.0.

Learning motivation as a mediator for the achievement of learning outcomes in this study shows a significant indirect effect of PCK on learning outcomes through learning motivation. This result is in line with Gumelar's research (2019), in which one of his research findings states that learning styles affect learning outcomes through learning motivation. Likewise, this study's results are in line with the results of Copriady's (2014) study, which states that the results show that motivation is a significant variable as a mediator between the variables of readiness with the ICT application in teaching and learning science and social science.

The implication of this study that the principal and the education office should continue to strive to improve the quality and smoothness of the teaching and learning process by providing provision to teachers to improve pedagogical content knowledge (PCK) learning management by participating in workshops and continuously improving techniques to motivate students for results. Students are learning better.

\section{CONCLUSION}

Based on the research results and analysis of research data and discussion, the following conclusions obtained that Pedagogical content knowledge learning management (PCK) has no significant direct effect on student learning outcomes. PCK learning management has a positive effect on learning motivation $\left(p_{12}=0.86\right)$. The relative contribution of PCK) learning management to learning motivation is $75 \%$. Learning motivation has a positive direct effect on student learning outcomes ( $\mathrm{P}_{Y_{2}}=0.58$ ). The relative contribution of learning motivation to student learning outcomes is $59 \%$.

\section{ACKNOWLEDGMENTS}

This article would not have been possible without the extraordinary support of Maman Rakhmanudin, who compiled the initial draft of the manuscript and collected the data. His enthusiasm, knowledge, and passion have inspired him. The Universitas Wiralodra, postgraduate school director, has facilitated writing articles, including checking transcriptions and proofreading and providing valuable insights.

\section{REFERENCES}

Azwar, S. (2017). Metode penelitian psikologi. Yogyakarta: Pustaka Pelajar Offset.

Barendsen, E., Henze, I. Relating Teacher PCK and Teacher Practice Using Classroom Observation. Res Sci Educ 49, 1141-1175 (2019). https://doi.org/10.1007/s11165-0179637-z. 
Budiaji, W. (2013). Skala Pengukuran dan Jumlah Respon Skala Likert. Jurnal IImu Pertanian dan Perikanan (JIPP). ISSN 2302-6308. 2(2) : 127 - 133.

Cheng L., Antonenko P., Ritzhaupt A.D., Dawson K., Miller D., MacFadden B.J., Grant C., Sheppard T.D. \& Ziegler M. (2020). Exploring the influence of teachers' beliefs and 3D printing integrated STEM instruction on students' STEM motivation. Computers \& Education. DOI: HTTPS:// doi.org/10.1016/j.compedu.2020.103983.

Copriady, J. (2014). Self-motivation is a mediator for teachers' readiness in applying ICT in teaching and learning. TOJET: The Turkish Online Journal of Educational Technology October 2014, volume 13 issue 4.

Creasy, J.A., Whipp, P.R. \& Jackson, B. (2012). Teachers' pedagogical content knowledge and students' learning outcomes in ball game instruction. ICHPER-SD Journal of Research, 7 (1). pp. 3-11.

Creswell, J. (2018). Research design: qualitative, quantitative, and mixed methods approach. 5th Edition. SAGE Publications, Inc.

Doyle, A., Seery, N., Gumaelius, L. et al. Reconceptualising PCK research in D\&T education: proposing a methodological framework to investigate enacted practice. Int J Technol Des Educ 29, 473-491 (2019). https://doi.org/10.1007/s10798-018-9456-1.

Erin E. Peters-Burton, Jordan Goffena \& Stephanie M. Stehle. (2020). The Utility of a selfregulated learning microanalysis for assessing learning during professional development. The Journal of Experimental Education. DOI: 10.1080/ 00220973.2020 .1799314

Ghozali, I. (2016). Aplikasi analisis multivariate dengan program IBM SPSS 23 (edisi 8). Cetakan ke viii. Semarang : Badan Penerbit Universitas Diponegoro.

Ghozali, I. \& Fuad. (2018). Structural Equation Modeling: Teori, Konsep dan Aplikasi dengan Program LISREL 9.10 (Edisi 4). Badan Penerbit Universitas Diponegoro. ISBN: 978.704.300.2

Pratama, G.P. \& Pinayani, A. (2019). Effect of Learning Style on Learning Outcomes with Mediator Variable Learning Motivation in International Conference on Economics, Education, Business and Accounting, KnE Social Sciences, pages 808-819. DOI 10.18502/CSS.v3i1 1.4052.

Khairil, H., Dazrullisa, M., Binari, \&Hasruddin. (2019). PCK analysis of teachers in the Biology Learning Process using teaching material based on local wisdom by integrating character education through PBI models. Journal of Physics: Conference Series 1477 (2020) 042056. IOP Publishing. DOI:10.1088/1742-6596/1477/4/042056

Hanggara, A (2016). Studi Pedagogical Content Knowledge (PCK) Guru. Disertasi. Bandung: Universitas Pendidikan Indonesia.

Hermawan, I. (2019). Metodologi penelitian pendidikan : kuantitatif, kualitatif dan mixed methods. Kuningan : Hidayatul Quran. ISBN: 978-623-91984-0-4 
Isdaryanti, B., Rachman, M., Sukestiyarno, Y. L, Florentinus, T. S. W,idodo. (2018). Teachers' Performance In Science Learning Management Integrated With Character Education. Jurnal Pendidikan IPA Indonesia, 7 (1), pp. 9 - 15. DOI: 10.15294/jpii.v7i1.12887

Usak, M., Ulker, R., Oztas, F. \& Terzi, I. (2013). The Effects of Professors' Pedagogical Content Knowledge on Elementary Teacher Candidates' Attitude and Achievement Regarding Biology. The Anthropologist, 16:1-2, 251- 261, DOI: 10.1080/09720073.2013.11891353

Jihad, A. \& Abdul Haris. (2013). Evaluasi Pembelajaran. Yogyakarta : Multi Pressindo

Keller, Melanie M.; Neumann, Knut; Fischer, Hans E. (2017). The Impact of Physics Teachers' Pedagogical ContentKnowledge and Motivation on Students' Achievement and Interest. Journal of Research in Science Teaching, v54 n5 p586-614 May 2017.

Krejcie, R.V., \& Morgan, D.W. (1970). Determining Sample Size for Research Activities. Educational and Psychological Measurement.

Lange, K., Klveckmann, T., and Möller, K. (2012). Elementary teachers' pedagogical content knowledge and student achievement in science education. In C. Bruguiere, A. Tiberghein \& P. Clement (Eds.). Science Learning and Citizenship. Proceedings of the Ninth ESERAConference 2011. Lyon.

Likert, R.A. (1932). A Technique for the Measurement of Attitudes. Archives of Psychology, 140 pp: $1-55$.

Mardawiah. (2016). Pengaruh Kompetensi Pedagogik Guru dan Motivasi Belajar Siswa terhadap Hasil Belajar Pelajaran IPS di SMP Negeri 2 Palu. E Jurnal Katalogis, 4 (11), hIm. 79-86, ISSN: 2302-2019

Maryani, I., Martaningsih, and Tutur, Sri. (2015). Correlation between Teacher's PCK (Pedagogical Content Knowledge) and Student's Motivation in Primary School. International Journal of Evaluation and Research in Education, v4 n1 p38-44 Mar 2015

OECD. (2016). PISA 2015 Results (Volume I): Excellence and Equity in Education. Paris: OECD Publishing

Purwanto, N. (2017). Psikologi pendidikan. Bandung: PT Remaja Rosdakarya

Rafiola, R., Setyosari, P., Radjah, C. \& Ramli, M. (2020). The Effect of Learning Motivation, Self-Efficacy, and Blended Learning on Students' Achievement in The Industrial Revolution 4.0. International Journal of Emerging Technologies in Learning (iJET), 15(8), 71-82. Kassel, Germany: International Journal of Emerging Technology in Learning. Retrieved October 7, from https://www.learntechlib.org/p/217073/.

Rahayu, T. dan Partono, T. (2017). Pengaruh Kompetensi Profesional Guru dan Minat Belajar Terhadap Hasil Belajar Siswa Melalui Motivasi Belajar Sebagai Variabel Intervening Pada Mata Pelajaran Ekonomi. Economic Education Analysis Journal, 6 (3), hlm. 711 726, e-ISSN: 2502-356X

IJEMI Vol.2, No.2, May 2021, pp. 183 198 
Riduwan. (2013). Rumus dan data dalam aplikasi statistik. Bandung: Alfabeta.

Rollnick, M. (2017). Learning about semiconductors for teaching-The role played by content knowledge in pedagogical content knowledge (PCK) development. Research in Science Education, 47(4), 833-868.

Sagala, S. (2013). Konsep dan makna pembelajaran. Bandung: Alfabeta

Santiago, Cueto, et al. (2017). Teacher's Pedagogical Content Knowledge and Mathematics achievement of students in Peru. Educ Stud Math, pp. 329-345, DOI 10.1007/s10649016-9735-2

Sardiman, A. M. (2014). Interaksi dan motivasi belajar mengajar. Jakarta: Grafindo Persada.

Sekaran, U. (2014). Metodologi penelitian untuk bisnis. Jakarta : Salemba Empat.

Senjaya, A. J. (2018). Langkah - langkah analisis statistik dalam riset bidang pendidikan dan sosial. Yogyakarta: K Media

Subarji. (2015). Peningkatan Pedagogical Content Knowledge Guru Matematika dan Praktiknya Dalam Pembelajaran Melalui Model Pelatihan Teqip. Jurnal IImu Pendidikan. 21 (1) hlm 71 - 79.

Sudijono, A. (2017). Pengantar evaluasi pendidikan. Jakarta: Rajawali Pers

Sudjana, N. (2014). Penilaian hasil proses belajar mengajar. Bandung: PT Remaja Rosdakarya

Sukadi, E., Cari, Sarwanto. (2015). Implementasi Pedagogical Content Knowledge Pada Materi Listrik Dinamis Untuk Meningkatkan Kompetensi Calon Guru Fisika. Jurnal Inkuiri, 4 (1), hlm. 37-46, ISSN: 2252-7893

Sumintono, B \& Widhiarso, W. (2013). Aplikasi model Rasch untuk penelitian ilmu-ilmu sosial. Jakarta: Tim Komunikata Publishing House

Sunarti, I. \& Susanti. (2016). Pengaruh Kompetensi Professional Guru Terhadap Motivasi Belajar Siswa serta Implikasinya Terhadap Hasil Belajar Siswa. Jurnal Equilibrium, 14 (02), hlm. 22-37, ISSN: 0216-5287

Triwiyanto, T. (2015). Manajemen kurikulum dan pembelajaran. Jakarta: PT. Bumi Aksara Undang-Undang Republik Indonesia Nomor 20 Tahun 2003 Tentang Sistem pendidikan Nasional

Widodo, A. (2017). Teacher Pedagogical Content Knowledge (PCK) and Students' Reasoning and Wellbeing. Journal of Physics: Conference Series, IOP Conf. Series: 812 (2017)012119

Wibisono, S. (2016). Aplikasi Model Rasch Untuk Validasi Instrumen Pengukuran Fundamentalisme Agama Bagi Responden Muslim. Journal Pengukuran Psikologi dan Pendidikan Indonesia (JP3I): 31 (1)2016.

Walter, E. M. (2013). The Influence of Pedagogical Content Knowledge (PCK) for Teaching Macroevolution on Student Outcomes in a General Education Biology Course. Proquest LLC, PhD. Dissertation, University of Missouri - Columbia. 
Wu TJ, Tai YN. (2016). Effects of Multimedia Information Technology Integrated Multi-Sensory Instruction on Students' Learning Motivation and Outcome. EURASIA J Math Sci Tech Ed. 2016;12(4):1065-74. https://doi.org/10.12973/eurasia.2016.1552a. 